\title{
Stomatal traits of maize grown by applying waste to soils under water stress conditions*
}

\author{
Damla BENDER ÖZENÇ iD 1 , Esra KUTLU SEZER ${ }^{2}$ \\ 1Department of Soil Science and Plant Nutrition, Faculty of Agriculture, Ordu University, Ordu 52100, Turkey \\ ${ }^{2}$ Algela Biotechnology, Gazi University Technopark, Ankara, Turkey
}

*This article was produced from the 2nd author's Master Thesis

Alınış tarihi: 30 Mart 2021, Kabul tarihi: 24 Mayıs 2021

Sorumlu yazar: Damla BENDER ÖZENÇ, e-posta: damlabender@hotmail.com

\begin{abstract}
Purpose: Drought will be one of the most important questions in the future. The easiest and natural way to drought recovery is to popularize the use of materials that will increase the water holding capacity of soils. The aim of this study is to determine the effect of hazelnut husk applying in water stress conditions on stomatal traits and the growth of maize.
\end{abstract}

Materials and Methods: A greenhouse experiment was conducted in a randomized plot design using three factors:hazelnut husk doses (30-60-80 t ha-1) and three water stress levels (at 75\%, 50\% and 25\% of field capacity); and two different soil texture (clay loam and sandy loam) with three replications.

Results: Root fresh weight, total biomass and root:shoot ratio increased by $73 \%, 51 \%$ and $39 \%$ respectively when plants grown in clay loam soil are compared with sandy loam soil. Hazelnut husk applications affected both plant growth and stomatal traits, the most effective dose was $80 \mathrm{t} \mathrm{ha}^{-1}$ but the dose of $60 \mathrm{tha}^{-1}$ was found sufficient for the stomatal traits. Water stress caused a significant decrease in shoot growth (16-52\%), leaf area (13-44\%) and stomatal traits whereas irrigation at $50 \%$ of field capacity with $60 \mathrm{t} \mathrm{ha}^{-1}$ of the husk was found sufficient.

Conclusion: It is thought that other morphological features are also not affected because hazelnut husk prevents the roots from being affected by stress. However, further studies are needed to determine the effects under field conditions.
Key words: Hazelnut husk, Zea mays L., Root-shoot growth, Soil texture, Stomatal trait

Su stres koşulları altında topraklara atık uygulayarak yetiştirilen mısırın stomatal özellikleri

Özet

Amaç: Kuraklık gelecekteki en önemli sorunlardan birisi olacaktır. Kuraklıkla mücadelenin en kolay ve doğal yolu, toprakların su tutma kapasitesini artıracak materyallerin kullanımını yaygınlaştırmaktır. Bu çalışmanın amacı, su stresi koşullarında uygulanan findık kabuğunun stoma özellikleri ve mısırın büyümesi üzerindeki etkisini belirlemektir.

Materyal ve Yöntem: Bu amaçla, tesadüf parselleri deneme deseninde 3 faktörlü bir sera denemesi yürütülmüștür: fındık zuruf dozları (30-60-80 tha-1), 3 su stres düzeyi (tarla kapasitesinin $\% 75$, $\% 50$ ve $\% 25$ 'i düzeyi); 2 farklı toprak tekstürü (killi tın ve kumlu tın) ve 3 tekrarlamalı olarak uygulanmıștır.

Araştırma Bulguları: Kumlu tın toprakla kıyaslandığında killi tın toprakta yetişen bitkilerin kök yaş ağırlık (\%73), toplam biokütle (\%51), kök:gövde oranı (\%39) artmıştır. Fındık kabuğu uygulamaları hem bitki büyümesini hem de stoma özelliklerini etkilemiş, en etkili doz $80 \mathrm{t} \mathrm{ha}^{-1}$ uygulamasıyd, ancak $60 \mathrm{tha}^{-1}$ dozu stoma özellikleri için yeterli bulunmuştur. Su stresi gövde gelişimini (\%16-52), yaprak alanı (\%13-44) ve stoma 
özelliklerinde önemli bir azalmaya neden olurken, $60 \mathrm{t}$ ha $^{-1}$ zuruf doz uygulamasinda tarla kapasitesinin \%50'si düzeyinde sulama yeterli bulunmuştur.

Sonuç: Fındık kabuğu köklerin stresden etkilenmesini engellediği için diğer morfolojik özelliklerin de etkilenmediği düşünülmektedir. Bununla birlikte, tarla koşullarındaki etkileri belirlemek için daha fazla çalışmaya ihtiyaç vardır.

Anahtar kelimeler: Fındık zurufu, Zea mays L., kökgövde gelişimi, toprak tekstürü, stomatal özellik

\section{Introduction}

Water stress is one of the most important environmental stresses that affect agricultural production worldwide (Hessine et al., 2009; Lisar et al., 2012). Undoubtedly, plants are exposed to water stress either for long or short periods of time during their life cycles (Pereira and Chaves, 1993). Maize is a plant growing during the hottest season of the year, water consumption is high. Besides, it is a plant that uses water most effectively among field crops. Bavec et al. (2015) expressed that the morphological parameters and photosynthetic ratios of maize decreased significantly in relation to stress. Water deficiency affects a large range of variables and functions in plants, such as stomata functioning and growth traits such as elongation rate, shoot:root ratio and specific leaf area (Time et al., 2018). The stomatal regulation determines water consumption of plants and affects the ability to survive under conditions of drought stress (Changhai et al., 2010).

Drought problems, which are frequently caused by climatic change, have made it necessary to keep the water in the soil and to increase its availability. For this purpose, one of the easiest and most natural ways is applications of materials that will increase the water holding capacity of soils. Nowadays, many organic wastes can be applied directly or after composting for these purposes. Compost is an important source of organic matter and the soil quality and improvement of soil health can be restored by incorporation of recycling organic wastes in the soil (Zhang et al., 2014).

Hazelnut is the most important agricultural product in Turkey, and its harvest residue (husk) is produced about 400000 t/year. Some physical and chemical properties of the hazelnut husk which can be used as an organic source was reported by Özenç and Çalışkan (2001). The hazelnut husk and compost applications increased the physical and chemical quality properties of soil (Zeytin and Baran, 2003; Gülser et al., 2015; Sezer and Özenç, 2018). Although there are studies about the effects of hazelnut husk on soil properties and maize development, studies on the effect under water stress conditions are insufficient. For this reason, it was aimed to determine the effect of hazelnut husk on stomatal traits and maize growth in different textured soils under water stress conditions.

\section{Materials and methods \\ Materials}

The experiment was conducted under greenhouse conditions (high tunnel) at the University of Ordu, Agricultural Faculty (Ordu, Turkey, $44^{\circ} 61^{\prime} \mathrm{N}$, $30^{\circ} 46^{\prime} \mathrm{E}$ ) in 2015 . Soil samples were collected from experimental station. Soil textures were classified as clay loam (CL) and sandy loam (SL). Soils were, slightly alkaline $(7.89,7.38)$, salt-free; and organic matter contents were $2.84 \%$ and $1.23 \%$, total nitrogen were $0.09 \%$ and $0.07 \%$, the available phosphorus contents were $6.82 \mathrm{mg} \mathrm{kg}^{-1}$ and $3.17 \mathrm{mg}$ $\mathrm{kg}^{-1}$, and potassium contents were $0.54 \mathrm{mg} \mathrm{kg}^{-1}$ and $0.36 \mathrm{mg} \mathrm{kg}^{-1}$ respectively for CL and SL. Field capacity values were low and $37.1 \%$ for CL and 10.8\% for SL (Sezer and Özenç, 2018). Hazelnut husk was taken from the pile which is kept under the natural conditions for 4 years. The hazelnut husk (HH) waste, which was used as a substrate, had low bulk density $\left(0.17 \mathrm{~g} \mathrm{~cm}^{-3}\right)$, high aeration capacity (32.85\%), and optimum available water content $(25.87 \%)$. The material had a high content of organic matter (64.02\%), adequate $\mathrm{pH}$ (7.07), insufficient $\mathrm{N}$ (1.05\%) and $\mathrm{P}$ (628 $\left.\mathrm{mg} \mathrm{kg}^{-1}\right)$ content, but had high and sufficient $\mathrm{K}\left(363 \mathrm{mg} \mathrm{kg}^{-1}\right)$ content.

'Mataro F1' hybrid variety was used for maize seed. It is located in the FAO 550 class and is harvested in the average of 110-115 days and is the most widely used in the region.

\section{Experimental design}

The experiment design was a three-factor fully randomized plot design. The treatments consisted of two soils (clay loam, sandy loam), four doses (0-3060-80 $\left.\mathrm{t} \mathrm{ha}^{-1}\right)$, three water-deficit stress levels $(75 \%$, $50 \%$ and $25 \%$ levels of field capacity) and replicated three times. Three $\mathrm{kg}$ pots were used for pot experiment. The amount of waste to be used according to the application doses was calculated (036- 72- $96 \mathrm{~g}$ hazelnut husk), and the media were prepared. At first, pots were covered by polyethylene 
to prevent water leakage, after prepared media were filled in pots and five maize seeds were sown in per pot at a depth of $5 \mathrm{~cm}$. All pots were irrigated at 75\% level of field capacity until the plants were 4-6 leaves, and plants were thinned to leave two seedlings in per pot. Then pots were covered by polyethylene for preventing evaporation, and a plastic pipe was placed into pots for irrigation. During the experiment, the plants were irrigated manually with these plastic pipes. The pots were grouped for water stress applications. Irrigation at $75 \%$ level of field capacity was evaluated as a control group, irrigations at $50 \%$ and $25 \%$ level of the field capacity were stress groups. The amount of water to be given to each stress group was calculated according to field capacity of soils. Water was applied by taking into account pot weight and the weight of the pipes placed in the pots. The amount of water consumed by plants was completed according to weight loss.

As basic fertilizers, $125 \mathrm{mg} \mathrm{kg}^{-1} \mathrm{~K} /$ pot and $100 \mathrm{mg}$ $\mathrm{kg}^{-1} \mathrm{P} /$ pot (as $\mathrm{KH}_{2} \mathrm{PO}_{4}$ ), $200 \mathrm{mg} \mathrm{kg}^{-1} \mathrm{~N} /$ pot (as $\mathrm{Ca}\left(\mathrm{NO}_{3}\right)_{2}$ ) and $2.5 \mathrm{mg} \mathrm{kg}-1 /$ pot (as $\mathrm{FeSO}_{4}$ ) were applied at sowing time. During the experiment period, no other fertilizers were used. The plants were harvested about 70 days before blooming.

\section{Methods}

At first, the plant height was measured from the soil surface to the top by ruler, then they were cut. The cut plants were first washed with tap water then with distilled water. Samples were dried with coarse blotter and fresh shoot weights were measured by three-digit balance. For leaf area measurements, the 5 th leaf of per plant was taken, and measured with a digital planimeter. Then, these leaves were combined with plant samples again to determine dry weight of plants. Samples were taken from the 6th leaves of per plant for stomatal width and length measurements then placed into a previously prepared $70 \%$ alcohol solution. The anatomical sections were taken from the upper and lower surfaces of these leaf samples with the help of razor blade. These samples were placed on the slides of the glycerin and covered with lamella and then were photographed with a Nikon FDX-35 microscope. NIS Elements was measured using the Imaging Software 3.0 SP5 program. Stomatal surface $(S S)$, was calculated using the following equation 1 (Wang et al., 2012).
$S S=S L \times S W \times \pi / 4$

To separate the plant roots, soils in pots were poured on the sieve placed in a container and washed. The washed roots were collected from the sieve and washed with distilled water. The washed roots were dried with coarse blotter and weights were measured by three-digit balance. Total biomass was calculated by sum of shoot and root fresh weight. After measurements, the root and shoot were dried in the oven at $65{ }^{\circ} \mathrm{C}$ for 48 hours and were weighed the dry weights; total dry matter, root:shoot ratio was calculated.

The data were subjected to analysis of variance (ANOVA) by using SAS-JUMP 11.0 statistical package. Significant differences among treatments were determined using least significant difference (LSD) multiple comparison test at $\mathrm{p}<0.05$ and the results were expressed in the form of a letter notation along with the averages. Pearson's correlation coeficients between morphological parameters and stomatal traits were calculated using SPSS 22.0 statistical package. The figures were drawn by Excel Software, and values in the figures and tables are the average of three replications and shown as the means and their standard deviations (SD).

\section{Results and Discussion}

\section{Effect of the treatments on plant morphological characteristics}

All measured properties were higher in plants growth in clay loam soil than in sandy loam soil (Table 1). The root fresh weight, total biomass, total dry matter, root:shoot ratio of plants grown in clay loam soil increased by $73 \%, 51 \%, 27 \%$, respectively. Also, hazelnut husk applications compared to the control group (except for root:shoot ratio), provided an increase $108 \%$ in root fresh weight, $67 \%$ in shoot fresh weight, $95 \%$ in total biomass, $63 \%$ in total dry matter.

The interaction of soil texture $\mathrm{x}$ the husk doses on the root fresh weight and total biomass was significantly different $(\mathrm{P}<0.05) \quad($ Table 1$)$. Husk applications compared to control increased root weight from $4 \%$ to $136 \%$ and total biomass from $4 \%$ to $125 \%$ in clay loam soil, similiarly from $12 \%$ to $68 \%$ and from $12 \%$ to $56 \%$ in sandy loam soil, respectively. The most effective dose was $80 \mathrm{t} \mathrm{ha}^{-1}$ husk application for both soil (Figure 1). 
Table 1. The effect of soil texture, husk doses and water stress levels on morphological properties of maize (mean values per plant)

\begin{tabular}{|c|c|c|c|c|c|}
\hline Treatments & RFW (g) & SFW (g) & TB (g) & TDM (g) & $\mathrm{R}: \mathrm{S}$ \\
\hline CL & $14.9 \mathrm{a}^{* *} \pm 8.3$ & $5.7^{\mathrm{ns}} \pm 2.3$ & $20.6 \mathrm{a}^{* *} \pm 10.0$ & $3.3 a^{* *} \pm 1.1$ & $2.8 \mathrm{a}^{* *} \pm 1.1$ \\
\hline SL & $8.6 b \pm 2.5$ & $5.0 \pm 2.7$ & $13.6 \mathrm{~b} \pm 4.1$ & $2.6 b \pm 0.6$ & $2.1 \mathrm{~b} \pm 0.7$ \\
\hline 0 & $8.4 \mathrm{~b}^{* *} \pm 2.4$ & $4.3 b^{* *} \pm 1.9$ & $12.7 c^{* *} \pm 3.1$ & $2.4 \mathrm{~b}^{* *} \pm 0.4$ & $2.7^{\mathrm{ns}} \pm 0.9$ \\
\hline 30 & $9.1 b \pm 2.7$ & $4.8 \mathrm{~b} \pm 1.3$ & $13.9 b c \pm 2.9$ & $2.6 b \pm 0.6$ & $2.4 \pm 1.2$ \\
\hline 60 & $11.9 \mathrm{~b} \pm 3.7$ & $5.2 \mathrm{~b} \pm 1.9$ & $17.1 b \pm-4.4$ & $2.9 b \pm 0.4$ & $2.3 \pm 0.8$ \\
\hline 80 & $17.6 \mathrm{a} \pm 10$ & $7.2 \mathrm{a} \pm 3.5$ & $24.8 a \pm 12.6$ & $3.9 \mathrm{a} \pm 1.3$ & $2.4 \pm 1.0$ \\
\hline LSD & 3.500 & 1.505 & 4.272 & 0.529 & \\
\hline \multicolumn{6}{|c|}{ Water stress (W) } \\
\hline $75 \%$ of $\mathrm{FC}$ & $11.3^{\mathrm{ns}} \pm 7.3$ & $6.4 a^{* *} \pm 2.8$ & $17.7^{\mathrm{ns}} \pm 9.3$ & $2.9^{\mathrm{ns}} \pm 1.0$ & $2.2^{\mathrm{ns}} \pm 0.9$ \\
\hline $50 \%$ of $\mathrm{FC}$ & $11.9 \pm 7.2$ & $5.5 a b \pm 2.6$ & $17.4 \pm 8.7$ & $3.1 \pm 0.9$ & $2.7 \pm 1.2$ \\
\hline $25 \%$ of FC & $12.0 \pm 6.1$ & $4.2 \mathrm{~b} \pm 1.6$ & $16.3 \pm 7.2$ & $2.8 \pm 1.0$ & $2.5 \pm 0.7$ \\
\hline LSD & & 1.304 & & & \\
\hline $\mathrm{TxD}$ & $*$ & ns & $*$ & ns & ns \\
\hline
\end{tabular}

*, **, ns: significant at $\mathrm{P}<0.05, \mathrm{P}<0.01$, and not significant, respectively. Values within column followed by the same letter are not significantly different at $\mathrm{P}<0.05$ (LSD test).

(RFW- Root Fresh Weight, SFW- Shoot Fresh Weight, TB- Total Biomass, TDM-Total Dry Matter, R:S- Root:Shoot Ratio)

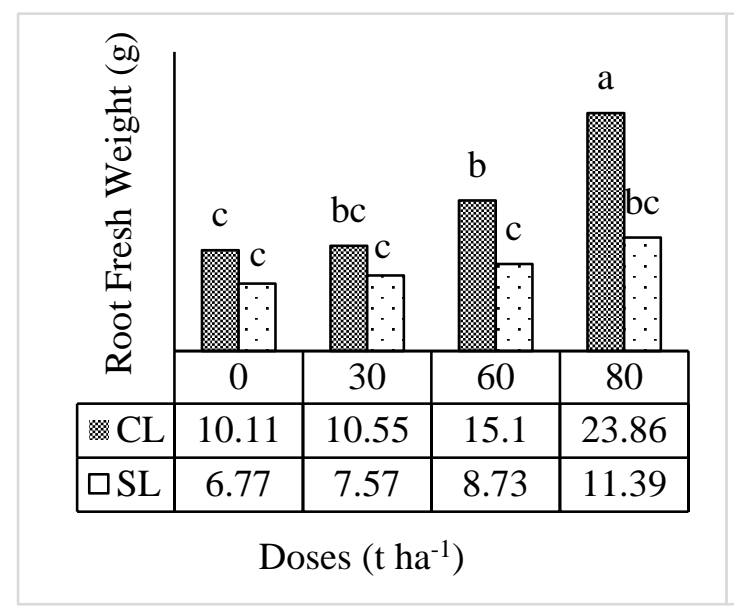

(a)

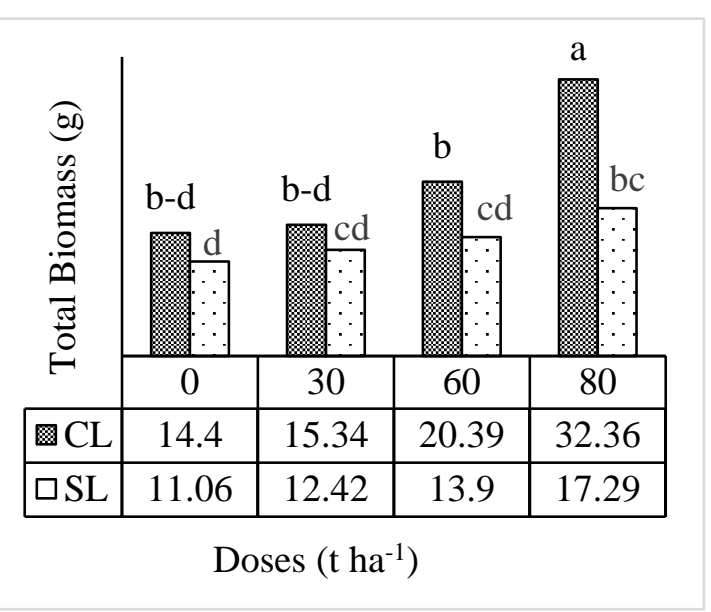

(b)

Figure 1. The interactions of soil texture and application doses on the root fresh weight (a) and total biomass (b) of maize

Environmental conditions such as soil air, soil moisture, soil texture have a significant impact on root development and growth (Kacar et al., 2009). Clay loam soil, which is naturally higher in clay content, the positive effect on aeration capacity and microbiological activity of the organic matter supplied with waste may have been more effective than sandy loam soil on root growth. As a result of increasing microporosity in sandy loam soils, it increased the available water capacity. The shoot growth of the plant is closely related to root growth, too. As the root growth increases, supply the nutrients and water needed by the plant due to the increase in the contact surface with the soil, has also increased and encouraged the shoot growth.
Hazelnut husk has high aeration, water retention capacity, organic matter content (Sezer and Özenç, 2018). Lower bulk density had supplied greater pore space and higher aeration, developing a suitable environment for biological activity. We thought that this effect was the result of the macroaggregation and decomposition products that the hazelnut husk formed by covering the primary soil particles. These results are in agreement with those reported by Bender Özenç and Özenç (2008), Belyaeva and Haynes (2010), Yazdanpanah et al. (2016), Hossain et al. (2017). These authors described that organic matter applications (such as hazelnut husk, manure and organic wastes) significantly increased total porosity, water holding capacity of soils, reduces 
bulk density and thus can improve soil physical and chemical properties.

Regardless the other treatments, water stress compared to control decreased shoot fresh weight (16\% and 52\%). The highest shoot weight was found in $75 \%$ of field capacity, following by at $50 \%$ of field capacity, both levels is the same significant group as statistically. This showed that irrigation at $50 \%$ of the field capacity is sufficient. This reduction could be due to a reduction in photosynthetic rate and low translocation rate of assimilates resulting from low leaf water potential and inhibition of chloroplast activity (Sokoto and Muhammad, 2014). With increased levels of stress, the cell wall weakens, cell volume decreased and pressure potantial descents, the low pressure potential leads to reduced of growth (Sumner, 2000), which will also affect yield.

\section{Correlations among morphological characterics}

Among the morphological characteristic attributes, the highest significant correlation of root fresh weight was observed with total biomass followed by that between total biomass and total dry matter. Total dry matter was found to be highly positively correlated with root fresh weight. (Table 2).

This relationship showed the importance of root growth in plant development and also a more effective on root growth of husk application in water stress conditions. It can be evaluated as providing the root growth by regulating the physical properties of both soil (water holding capacity, aeration capacity, etc.) the applied husk in water stress conditions.

Table 2. Correlations (Pearson) among morphological characteristics $(n=72)$ of maize

\begin{tabular}{lccccc}
\hline & $\begin{array}{c}\text { Root fresh weight } \\
\text { (FRW, g) }\end{array}$ & $\begin{array}{c}\text { Shoot fresh weight } \\
\text { (FSW, g) }\end{array}$ & $\begin{array}{c}\text { Total biomass } \\
(\mathrm{TB}, \mathrm{g})\end{array}$ & $\begin{array}{c}\text { Total dry matter } \\
(\mathrm{TDM}, \mathrm{g})\end{array}$ \\
\hline RFW & 1 & $0.493^{* *}$ & $0.965^{* *}$ & $0.800^{* *}$ & $\begin{array}{c}\text { Root:Shoot ratio } \\
(\mathrm{R}: \mathrm{S})\end{array}$ \\
SFW & & 1 & $0.704^{* *}$ & 0.134 & $0.575^{* *}$ \\
TB & & & 1 & $0.827^{* *}$ & -0.100 \\
TDM & & & & 0.80 \\
R:S & & & & 0.50 \\
\hline
\end{tabular}

** Significant at 0.01 level, *Significant at 0.05 level

Dien et al. (2017) expressed that root and shoot development depended on the drought stress levels; and root dry weight was less affected than that of shoots under moderate drought.

The lowest and negative correlation was between root:shoot ratio and shoot fresh weight $\left(r^{2}=-0.100\right)$. Benjamin et al. (2014) stated that there was a negative correlation between root and stem biomass due to water stress during different developmental periods of corn plant and that it caused an increase in root:shoot ratio during all developmental periods depending on increasing water stress.

\section{Effect of the treatments on stomatal traits and} leaf area

The soil texture caused only significant differences on stomatal widht and length. The highest stomatal length was obtained in the clay loam soil, but the highest stomatal width was obtained for plants grown in sandy loam soil (Table 3). Stoma density and stoma size vary greatly depending on environment in which plant species grow and the structure of the foliage plant (Orcen et al., 2013). Likewise, when application doses increased, the leaf area (7\%-52\%), stomatal width (8\%-21\%), stomatal lenght (3\%-12\%) and stomatal space (19\%-57\%) also increased (Table 3). The most effective dose on the leaf area was $80 \mathrm{t} \mathrm{ha}^{-1}$ of husk application, and 60 $\mathrm{t} \mathrm{ha}^{-1}$ of husk application was found to be sufficient in other investigated properties. This is closely related to the physical properties of husk waste, and especially to the increase of the available water content of the soil when mixed with the soil (Zeytin and Baran, 2003; Bender Özenç and Özenç, 2008).

Furthermore, the water stress applications decreased leaf area (13-44\%) and stomatal space (1$5 \%$ ) whereas stomatal widht was higher at $50 \%$ of field capacity (Table 3). Maize plants subjected to drought showed decreased growth and stomatal conductance (Riboldi et al., 2016), stomatal density, stomatal area and the number of stomata per leaf and the stomatal size (Fan et al., 2013; Das et al., 2015), and also significantly decreased stomatal length and increased stomatal width (Zheng et al., 2013).

On the other hand, effect of the water stress $\mathrm{x}$ husk doses interaction on leaf area was significantly different (Figure 2). The lowest leaf area was obtained in control condition (non-husk) under 
water stress conditions of $25 \%$ of field capacity, about 2.2 fold decrease has occurred. As a result of water stress, leaf biomass decreased in the plant, and it was observed that aging and death occurred in leaves.

Ludlow and Muchow (1990) reported that lack of photosynthesis due to loss of turgor in the leaves with the closure of stomata in water-limited environments, cell growth is adversely affected. The mechanism of stomatal closure is considered as one of the highest factors of photosynthesis limitation (Flexas et al., 2014). The highest leaf area was obtained at a stress level of $50 \%$ of the field capacity and $80 \mathrm{t} \mathrm{ha}^{-1}$ of the husk application $\left(76.10 \mathrm{~cm}^{2}\right)$. It can be said that hazelnut husk increases the retention and availability of the water in the soil, and plants more benefit from this water, thereby reducing the adverse effects of water stress.

Table 3. The effect of soil texture, husk doses and water stress levels on leaf area and stomatal traits (mean values per plant)

\begin{tabular}{|c|c|c|c|c|}
\hline Treatments & LA $\left(\mathrm{cm}^{2}\right)$ & $\mathrm{SW}(\mu \mathrm{m})$ & $\mathrm{SL}(\mu \mathrm{m})$ & $\mathrm{SS}\left(\mu \mathrm{m}^{2}\right)$ \\
\hline \multicolumn{5}{|l|}{ Texture (T) } \\
\hline CL & $53.03^{\mathrm{ns}} \pm 17.01$ & $21.28 b^{*} \pm 2.56$ & $34.46 \mathrm{a}^{*} \pm 3.12$ & $620^{\mathrm{ns}} \pm 189.5$ \\
\hline SL & $48.49 \pm 12.77$ & $22.36 a \pm 2.68$ & $32.83 \mathrm{~b} \pm 2.39$ & $626 \pm 170.49$ \\
\hline \multicolumn{5}{|l|}{ Doses (D) } \\
\hline 0 & $42.54 c^{* *} \pm 10.07$ & $19.59 c^{*} \pm 1.97$ & $31.83 c^{* *} \pm 2.09$ & $492 b^{* *} \pm 108.80$ \\
\hline 30 & $45.91 b c \pm 11.88$ & $21.22 \mathrm{~b} \pm 2.37$ & $33.07 b c \pm 1.69$ & $588 \mathrm{ab} \pm 123.14$ \\
\hline 60 & $49.89 b \pm 10.24$ & $22.69 a \pm 1.66$ & $34.07 \mathrm{ab} \pm 2.65$ & $638 a \pm 137.79$ \\
\hline 80 & $64.69 a \pm 17.41$ & $23.77 a \pm 2.60$ & $35.62 \mathrm{a} \pm 3.51$ & $775 a \pm 208$ \\
\hline LSD & 6.578 & 1.351 & 1.745 & 84.225 \\
\hline \multicolumn{5}{|c|}{ Water stress (W) } \\
\hline $75 \%$ of FC & $59.10 \mathrm{a}^{* *} \pm 9.75$ & $21.78 \mathrm{ab}^{* *} \pm 1.92$ & $34.25^{\mathrm{ns}} \pm 2.34$ & $638 a^{*} \pm 173.98$ \\
\hline $50 \%$ of $\mathrm{FC}$ & $52.02 \mathrm{~b} \pm 17.60$ & $22.65 a \pm 3.32$ & $33.62 \pm 3.54$ & $627 b \pm 185.90$ \\
\hline $25 \%$ of $\mathrm{FC}$ & $41.15 c \pm 11.37$ & $21.01 b \pm 2.38$ & $33.06 \pm 2.61$ & $606 b \pm 183.15$ \\
\hline LSD & 5.696 & 1.169 & & 72.945 \\
\hline WxD & $*$ & ns & ns & ns \\
\hline
\end{tabular}

$*^{* *}$, ns: significant at $\mathrm{P}<0.05, \mathrm{P}<0.01$, and not significant, respectively. Values within column followed by the same letter are not significantly diferent at $\mathrm{P}<0.05$ (LSD). (LA-Leaf Area, SW-Stomatal Width, SL- Stomatal Lenght, SS- Stomatal Space)

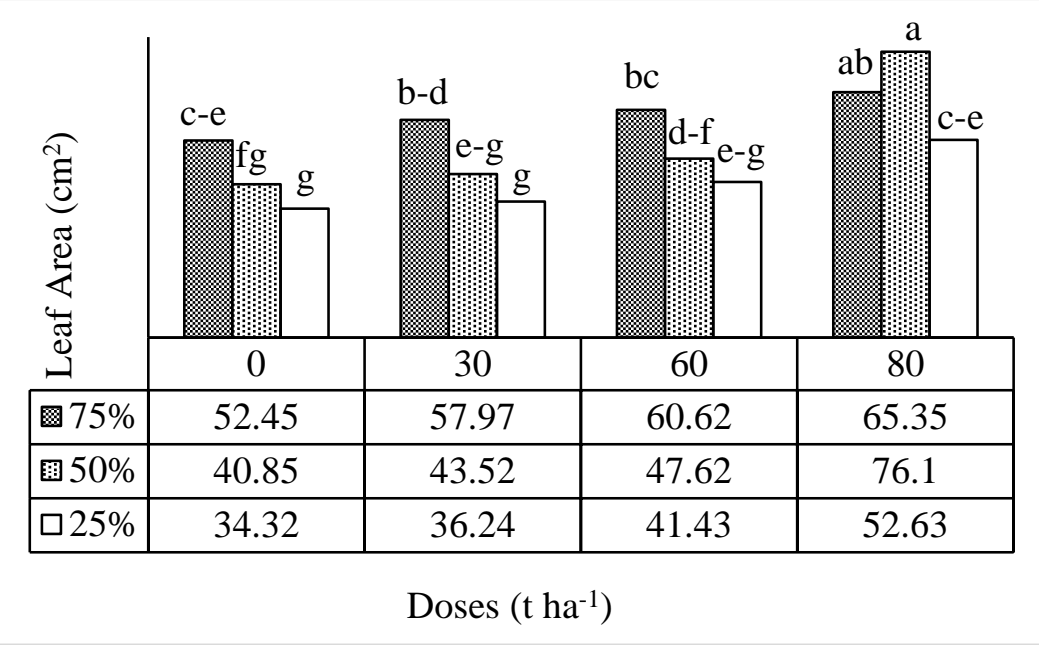

Figure 2- The interactions of application doses and water stress on the leaf area $\left(\mathrm{cm}^{2}\right)$ of maize

\section{Correlations of morphological characterics with stomatal traits}

Among the stomatal traits attributes, the highest significant correlation of stomatal lenght was observed with total dry matter followed by leaf area and total dry matter (Table 4). The ability of plants to be able to regulate the size of the stomatal opening is a very important mechanism to control water loss and survival, also is a response to the drying of the soil (Changhai et al., 2010).

This study indicated that hazelnut husk applications increased the availability of water although stomatal aperture and stomatal space reduced under water stress conditions for both soil texture. Leaf micromorphology was used as an indicator of drought tolerance, and have confirmed that stomatal 
density is positively correlated with drought stress (Fan et al., 2013; Bavec et al., 2015). Under water stress due to lack of water, which is a very important limiting factor in plant growth, significantly reduces the total number of leaves, shoot height and total leaf areas (Yin et al., 2005; Ge et al., 2012).

Table 4. Correlations (Pearson) among stomatal traits and morphological characteristics ( $\mathrm{n}=72$ ) of maize

\begin{tabular}{|c|c|c|c|c|}
\hline & $\begin{array}{l}\text { Root fresh weight } \\
\text { (g) }\end{array}$ & $\begin{array}{c}\text { Shoot fresh weight } \\
\text { (g) }\end{array}$ & Total biomass (g) & $\begin{array}{c}\text { Total dry matter } \\
(\mathrm{g})\end{array}$ \\
\hline Leaf area & $0.473^{* *}$ & $0.579^{* *}$ & $0.561^{* *}$ & $0.581^{* *}$ \\
\hline Stomatal width & $0.289^{*}$ & $0.297^{*}$ & $0.326^{* *}$ & $0.320^{* *}$ \\
\hline Stomatal length & $0.515^{* *}$ & $0.372^{* *}$ & $0.533^{* *}$ & $0.612^{* *}$ \\
\hline Stomatal space & $0.404^{* *}$ & $0.318^{* *}$ & $0.426^{* *}$ & $0.356^{* *}$ \\
\hline
\end{tabular}

** Significant at 0.01 level, *Significant at 0.05 level

\section{Conclusion}

Our results showed that the applications of hazelnut husk increased the growth, leaf area and stomatal traits of plant in both soils. This is the result of positive correlation of stomatal traits with morphological parameters. Although the most effective dose was $80 \mathrm{t} \mathrm{ha}^{-1}$, the dose of $60 \mathrm{t} \mathrm{ha}^{-1}$ was found sufficient. Water stress caused a significant decrease in shoot development, leaf area, stomatal width and stomatal space, but did not effect other parameters. The reason why it is not effective on other morphological parameters can be explained by the fact that hazelnut husk prevents the roots from being affected by stress due to the increase in the available water content of the soils. When all the parameters are taken into consideration, hazelnut husk could be effective application to enhance tolerance to water stress of maize in both soils. However, further studies are needed to determine the effects under field conditions.

\section{Conflict of interest}

There is no conflict of interest between the authors.

\section{Declaration of contribution}

DBÖ: Establishing, conducting of the research and evaluating the results. EKS: Establishing, conducting analyzing of the research

\section{Ackowledgements}

Financial funding for this research was provided by the Scientific Research Projects Coordination (Project No: TF-1429) Unit of Ordu University.

\section{References}

Bavec, F., Bavec, M., Mlkar, S.G., \& Fekonfa, M. (2015). Sweet maize growth and yield response to organic and mineral fertilizers, $\mathrm{N}$ rates and soil water regimes. Agricultura, 12 (1-2), 33-40.
Belyaeva, O.N., \& Haynes, R.J. (2010). A comparison of the properties of manufactured soils produced from composting municipal green waste alone or with poultry manure or grease trap/septage waste. Biology and Fertility of Soils, 46 (3), 271-281.

Bender Özenç, D., \& Özenç, N. (2008). Short-term effects of hazelnut husk compost and organic amendment applications on clay loam soil. Compost Science \& Utilization, 16 (3), 192-199.

Benjamin, J.G., Nielsen, D.C., Vigil, M.F., Mikha, M.M., \& Calderon, F. (2014). Water deficit stress effects on corn (Zea mays L.) root:shoot ratio. Journal of Soil Science, 4, 151-160.

Changhai, S., Baodi, D., Yunzhou, Q., Yuxin, L., Lei, S., Mengyu, L., \& Haipei, L. (2010). Physiological regulation of high transpiration efficiency in winter wheat under drought conditions. Plant Soil Environment, 56, 340-347.

Das, R., Bhagawati, K., Boro, A., Medhi, T., Medhi, B., \& Bhanisana, R.K. (2015). Relative performance of plant cultivars under respective water deficit adaptation strategies: A case study. Current World Enviroment, 10 (2), 683-690.

Dien, C.D., Yamakawa, T., Mochizuki, T., \& Htwe, A.Z. (2017). Dry weight accumulation, root plasticity, and stomatal conductance in rice (Oryza sativa L.) varieties under drought stress and re-watering conditions. American Journal of Plant Sciences, 8, 3189-3206.

Fan, X.W., Huang, G., Zhang, L., Deng, T., \& Li, Y. (2013). Adaptability and recovery capability of two maize inbred-line foundation genotypes, following treatment with progressive water-deficit stress and stress recovery. Agricultural Sciences, 4 (8), 389398.

Flexas, J., Diaz-Espejo, A., Gago, J., Gallé, A., Galmés, J., Gulías, J., \& Medrano, H. (2014). Photosynthetic limitations in Mediterranean plants: A review. Environ. Exp. Bot., 103, 12-23. 
Ge, T., Fanggong, S., Liping, B., Cheng-li, T., \& Ningbo, S. (2012). Effects of water stress on growth, biomass partitionig, and water-use efficiency in summer maize (Zea mays L.) throughout the growth cycle. Acta Physiol Plant, 34, 1043-1053.

Gülser, C., Kızılkaya, R., Aşkın, T., \& Ekberli, İ. (2015). Changes in soil quality by compost and hazelnut husk applications in a hazelnut orchard. Compost Science \& Utilization, 23, 135-141.

Hessine, K., Martínez, J.P., Gandour, M., Albouchi, A., Soltani, A., \& Abdelly, C. (2009). Effect of water stress on growth, osmotic adjustment, cell wall elasticity and water-use efficiency in Spartina alterniflora. Environmental and Experimental Botany, 67 (2), 312-319.

Hossain, M.Z., von Fragstein und Niemsdorff, P., \& Heß, J. (2017). Effect of different organic wastes on soil properties and plant growth and yield: A Review. Scientia Agriculturae Bohemica, 48 (4), 224-237.

Kacar, B., Katkat, A.V., \& Öztürk, Ş. (2009). Bitki Fizyolojisi. Nobel Yayınları, ISBN 978-975-591-833-4, Ankara.

Lisar, S.Y., Motafakkerazad, R., Hossain, M.M., \& Rahman, I.M. (2012). Water Stress in Plants: Causes, effects and responses. In book: Water stress, Chapter: 1 (Eds: Ismail, M.M. Rahman, Hiroshi Hasegawa), pp. 1-14. InTech: Rijeka, Croatia.

Ludlow, M.M., \& Muchow, R.C. (1990). A critical evaluation of traits for improving crop yields in water-limited environments. Adv. Agron., 43, 107-153.

Orcen, N., Nazarian, G., Barlas, T., \& Irget, E. (2013). Variation in stomatal traits based on plant growth parameters in corn (Zea mays L.). Annals of Biological Research, 4 (11), 25-29.

Özenç, N., \& Çalışkan, N. (2001). Effect of husk compost on hazelnut yield and quality. Proceedings of the Fifty International Congress on Hazelnut. Acta Horticulturae, 556, 559-566.

Pereira, J.S., \& Chaves, M.M. (1993). Plant water deficits in Mediterranean ecosystems. Water deficits plant responses from cell to community. (ed. by J.A. Smith, H. Griffiths). pp. 237-251. BIOS Sci. Ltd. Oxford.
Riboldi, L.B., Oliveira, R.F., \& Angelocci, L.R. (2016). Leaf turgor pressure in maize plants under water stress. Australian Journal of Crop Science, 10 (6), 878-886.

Sezer, E.K., \& Özenç, D.B. (2018). Effects on growth parameters of maize of hazelnut husk compost applications under water stress conditions. Journal of Soil Science and Plant Nutrition, 6 (1), 52-60.

Sokoto, M.B., \& Muhammad, A. (2014). Response of rice varieties to water stress in sokoto, Sudan savannah, Nigeria. J Biosci Med., 2 (1), 68-74.

Sumner, M.E. (2000). Beneficial use of effluents, waste, and biosolids. Communications in Soil and Plant Analyses, 31 (11-14), 1701-1715.

Time, A., Garridol, M., \& Acevedo, E. (2018). Water relations and growth response to drought stress of Prosopis tamarugo Phil. A review. Journal of Soil Science and Plant Nutrition, 18 (2), 329-343.

Wang, H., Shi, H., Yang, R., Liu, J., \& Yu, Y. (2012). Stomatal characteristics of greening plant species in response to different urban atmospheric environments in Xi'an China. J. Food Agric. Environ., 10 (3-4), 1524-1529.

Yazdanpanah, N., Mahmoodabadi, M., \& Cerda, A. (2016). The impact of organic amendments on soil hydrology, structure and microbial respiration in semiarid lands. Geoderma, 266, 58-65.

Yin, C., Wang, X., Duan, B., Luo, J., \& Li, C. (2005). Early growth, dry matter allocation and water use efficiency of two sympatric Populs species as affected by water strees. Environmental and Experimental Botany, 53 (3), 315-322.

Zeytin, S., \& Baran, A. (2003). Influences of composted hazelnut husk on some physical properties of soils. Bioresource Technology, 88, 241-244.

Zhang, X., Wu, X., Zhang, S., Xing, Y., Wang, R., \& Liang, W. (2014). Organic amendment effects on aggregateassociated organic C, microbial biomass C and glomalin in agricultural soils. Catena, 123, 188-194.

Zheng, Y., Xu, M., Hou, R., Shen, R., Qiu, S., \& Ouyang, Z. (2013). Effects of experimental warming on stomatal traits in leaves of maize (Zea mays L.). Ecology and Evolution, 3 (9), 3095-3111. 